\title{
The invasion ecology of mammals: a global perspective
}

\author{
Mick N. Clout ${ }^{\mathrm{A}, \mathrm{B}}$ and James C. Russel/ ${ }^{\mathrm{A}}$ \\ ${ }^{A}$ Centre for Biodiversity and Biosecurity, School of Biological Sciences, University of Auckland, \\ Private Bag 92019, Auckland 1142, New Zealand. \\ BCorresponding author. Email: m.clout@auckland.ac.nz
}

\begin{abstract}
Of the extant species of land mammals, $124(2.6 \%)$ can be classed as 'successful invaders', whereas 1038 $(21.6 \%)$ are classed as threatened, according to the 2006 IUCN Red List. Relatively high proportions of successful invaders are found among Artiodactyla, Carnivora, Lagomorpha and Perissodactyla. Compared with other organisms, mammals seem relatively likely to become established when introduced outside their natural range. Studies of determinants of invasion success indicate that the number of individuals released, the size of the natural range of the introduced species, and the temperateness of climate in the new range can all increase the probability of establishment of introduced mammals. Negative impacts of invasive mammals on native biodiversity include direct effects such as predation, browsing and competition, but can extend to disruption of patterns of nutrient flow, and trophic cascades. Eradication of several species of invasive mammals from increasingly large areas is now possible. In this context, it is important to better understand ecological interactions between such mammals (and between them and other species) to avoid unwanted consequences such as mesopredator or competitor release, after the removal of particular species. Finally, it is increasingly apparent that research is needed on the behaviour of dispersing and invading individuals, to improve the early detection of new mammal invasions or reinvasions.
\end{abstract}

\section{Introduction}

The deliberate or accidental introduction of species beyond their native range has been a historical consequence of human migration and trade, and has accelerated greatly in recent times. Several introduced species (including most crops and domestic livestock) are largely beneficial, but many others have become weeds or pests. Some have proved to be highly invasive, modifying natural ecosystems and threatening native species,

The process of biological invasion is now widely accepted to consist of a series of stages: introduction (or transport), establishment, and spread (Mack et al. 2000; Kolar and Lodge 2001). Terminology surrounding the phenomenon of biological invasions has, however, been a subject of recent debate (Colautti and MacIsaac 2004).

Mammals were among the first organisms to be introduced by humans: as livestock (sheep, goats, cattle), as companions (dogs) or as commensals (rodents). More recently, many other species of mammals have been deliberately introduced as sporting animals, for novelty reasons, and (ironically) to control previously introduced species that had proved to be pests. Overall, mammals are perhaps the best documented of all introduced organisms and have been the subject of two global compilations (Lever 1985; Long 2003) and some excellent regional records of attempted and successful introductions (Thomson 1922; Myers 1986; Jeschke and Strayer 2005).

The purpose of our review is first to examine differences between mammal groups in their propensity to contain successful invaders or threatened species. We then review the literature on determinants of invasion success by mammals and consider overall implications for the management of invasive mammals.

\section{Methods}

We searched the comprehensive book by Long (2003) for mammal species that have been recorded as being introduced and establishing a self-sustaining wild population in at least one location outside their natural range. Such species were classed as 'successful invaders', and included probable ancient introductions and introductions for conservation purposes outside the natural range. We excluded unconfirmed prehistoric introductions, reintroductions for conservation purposes within the natural range, scientific trials, and all instances where there is doubt (according to Long 2003) that a self-sustaining wild population was established. We included cases where a selfsustaining wild population was subsequently eradicated by human actions, but excluded those where populations died out naturally or where Long (2003) expresses any doubt about their fate. For analysis of the proportions of the various mammal groups that are successful invaders, we used the global list of wild mammals compiled by Ceballos et al. (2005), which incorporates data from the IUCN Red List. For completeness, we added to this list eight domesticated mammal species - goat (Capra hircus), sheep (Ovis aries), horse (Equus caballus), donkey (Equus asinus), cattle (Bos taurus), water buffalo (Bubalus bubalis), dog (Canis familiaris), and cat (Felis catus) - that are recorded by Long (2003) as having established truly unmanaged wild (feral) populations. For comparison with the proportions of the various mammal groups that are classed as threatened (i.e. vulnerable, endangered or critical, according to 2006 IUCN Red List criteria), we also followed the global mammal list compiled by Ceballos et al. (2005). For both 
analyses we excluded marine mammals (Cetacea, Pinnipedia, Sirenia) and all extinct species.

\section{The taxonomic distribution of mammalian invaders}

Our dataset contains 4816 species of extant land mammals, including domesticated species. Of these extant land mammals, $124(2.6 \%)$ can be classed as 'successful invaders', according to our criteria and the data compiled by Long (2003), whereas $1038(21.6 \%)$ are classed as threatened, according to the 2006 IUCN Red List. Overall proportions of successful invaders range from $0 \%$ (e.g. Chiroptera) to $14.7 \%$ (Artiodactyla), whereas proportions of threatened species range from $0 \%$ (e.g. Edentata) to $100 \%$ (Proboscidea) (Fig. 1). The orders Artiodactyla (pigs, camels, deer, cattle, sheep, goats and antelope), Carnivora (canids, bears, mustelids and cats), Lagomorpha (rabbits and hares), and Perissodactyla (equines) all contain high proportions of successful invaders. The mammal family with the highest proportion of successful invaders is Cervidae (29.2\%). Only $1.8 \%$ of the order Rodentia can be classed as successful invaders, but $13 \%$ of the genus Rattus have this dubious distinction.
The absence of any successful invaders among over 1000 species of bats, compared with (for example) 32 successful invaders among 217 species of Artiodactyla suggests that there are differences in the propensity of different groups to be transported and establish outside their natural range. Contrasts in the proportion of successful invaders between major taxonomic groups seem to be largely due to differences in propensity for deliberate introduction of species valued for hunting, as furbearers, as domestic animals, as biological control agents, or as easily transported novelties. For example, bats and insectivores are less favoured than deer and rabbits. Beyond this initial human 'filter', other biological determinants of success become important.

A relatively small number of mammal species have successfully established at more than 30 locations around the world (Long 2003). They include feral domestic animals (horses, sheep, goats, cattle, pigs, donkeys, cats, dogs), European rabbits (Oryctolagus cuniculus), red deer (Cervus elaphus), American mink (Mustela vison), Indian mongoose (Herpestes javanicus) and six species of rodents. The rodents include two deliberately introduced species - coypu (Mycocastor coypus) and muskrat

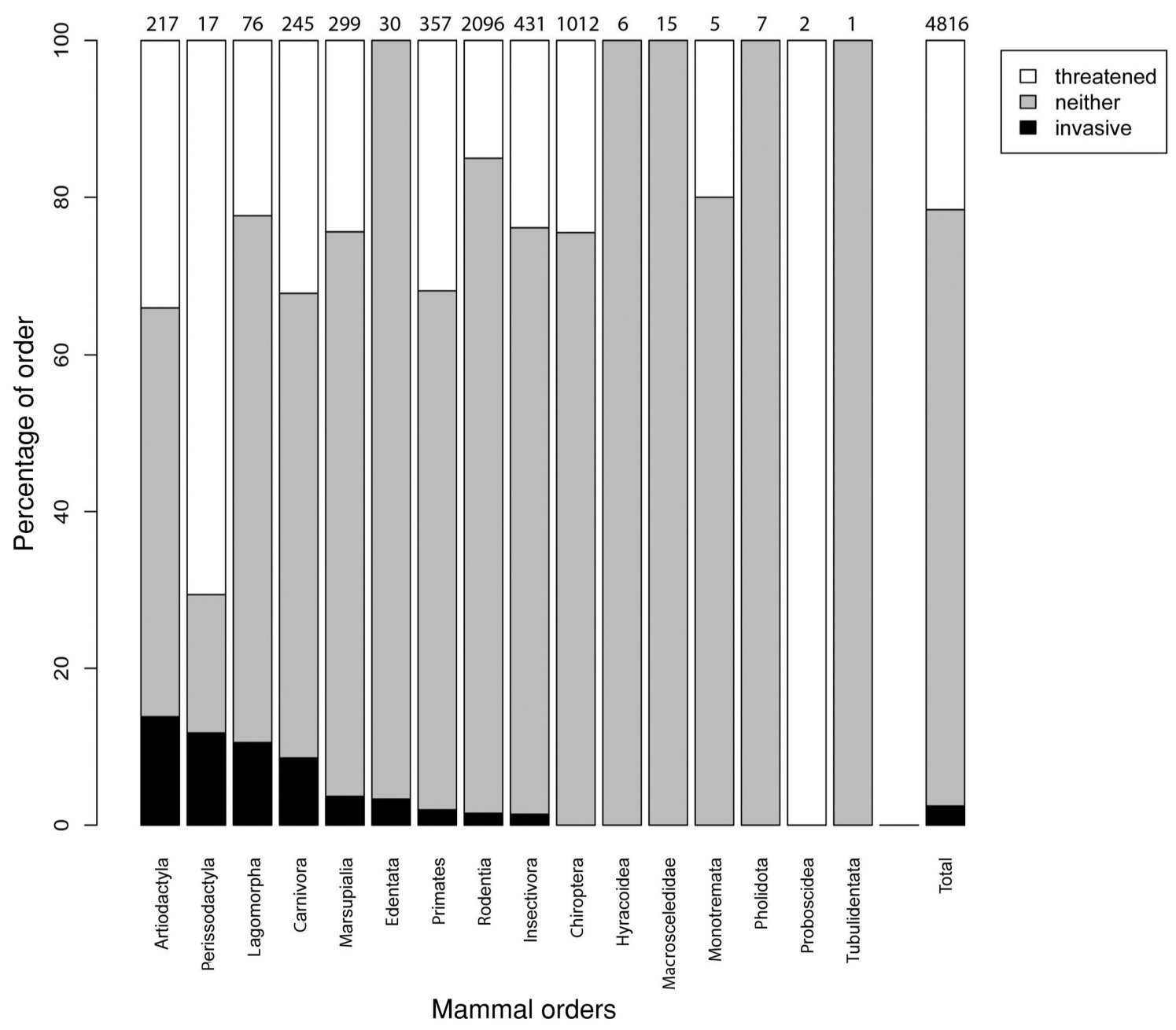

Fig. 1. Percentage of successful invaders, threatened species and those in neither category, for each mammalian order. The number of species in each order is shown above each bar. Nomenclature follows Long (2003) for orders Edentata, Insectivora and Marsupialia. 
(Ondatra zibethicus) - and four very widespread commensal species that have been accidentally introduced to many locations (Rattus rattus, $R$. norvegicus, $R$. exulans and Mus musculus).

\section{Determinants of invasion success}

Although less than $3 \%$ of the world's mammals can be classed as 'successful invaders', the data compiled by Long (2003) reveal that many of these species have also been the subject of unsuccessful introductions. Some other mammal species (excluding those reintroduced for conservation purposes) have never been successfully introduced, despite efforts to do so. These observations raise the question of what determines invasion success, a topic that has been the subject of several recent studies.

From an analysis of the invasion success of mammals, fish and birds in Europe and North America, Jeschke and Strayer (2005) demonstrate that introduced vertebrates have a relatively high probability $(\sim 50 \%)$ of establishing and spreading. They conclude that the 'tens rule' of Williamson (1996) (that $\sim 10 \%$ of species will make each of these transitions) does not apply to vertebrates. They also show that there is no clear difference in invasion success of vertebrates introduced from Europe to North America or vice versa.

The excellent records kept by Acclimatisation Societies in New Zealand (Thomson 1922) have provided a fertile source of data for analyses of factors affecting introduction success. In a study of the outcomes of introductions of 14 ungulate species, Forsyth and Duncan (2001) showed that the 11 successful species had shorter maximum life spans and were introduced in greater numbers than the unsuccessful ones. For all independent introductions there was a highly significant relationship between the number of individuals introduced and introduction success, with an apparent threshold introduction size of about six individuals, above which success was likely. A more recent analysis by the same authors (Duncan and Forsyth 2006) examined population persistence of 164 introductions of six mammal species (rabbit, goat, sheep, cat, pig and brushtail possum) to 85 islands in New Zealand. They show that small populations were initially at greatest risk of extinction; those that survived for 25 years were likely to persist for much longer; and the probability of mammal populations persisting on islands declined markedly with increasing latitude. A study of the species richness of 17 large and small introduced mammals on 297 islands in New Zealand (Russell et al. 2004) revealed that human transportation, facilitated by wharves and permanent inhabitants, increased the likelihood of introduced mammals being present, although small mammals were also dispersing by swimming to many islands.

Forsyth et al. (2004) analysed data on 40 mammal species introduced to mainland Australia, 23 of which successfully established. They found that successful species had a greater area of climatically suitable habitat available to them, had larger overseas ranges, and were introduced more times. Overall results were similar to those obtained for introduced birds in the same region (Duncan et al. 2001). In both groups, established species that had spread to occupy a large range in Australia also tended to be species of small body masses with more offspring per year. Among mammals, these more widespread species tended to be carnivores or omnivores, rather than herbivores
(Forsyth et al. 2004). Burbidge and Manly (2002) demonstrated a relationship between native mammal extinctions on Australian Islands and the presence of introduced European foxes (Vulpes vulpes) and feral cats.

\section{Implications for the management of invasive mammals}

Some introduced mammals have not only successfully established self-sustaining populations, but have also spread and have caused significant impacts in the ecosystems that they have invaded. Such species can be classed as invasive ('widespread and locally dominant'), according to the definition of Colautti and MacIsaac (2004). Examples of indisputably invasive mammals are the three widespread Rattus species (Amori and Clout 2003), European rabbits, feral cats, several species of deer, several mustelids and viverrids, and some other top predators such as the European fox and Arctic fox (Alopex lagopus). Further introductions (or range extensions) of such invasive species should be prevented wherever possible, and their eradication undertaken where feasible. The eradication of introduced mammals has progressed substantially in recent decades (Veitch and Clout 2002), especially from islands in countries such as New Zealand (Clout and Russell 2006). Removal of a range of mammals from increasingly large areas is now possible using a range of techniques. Successful eradications have now included the removal of rats from islands as large as 11300 ha (Towns and Broome 2003), and the eradication of coypu from a large area of south-eastern England (Gosling and Baker 1989).

\section{Changes to ecosystem processes}

Losses of native biodiversity (including the extinction of endemic species) as a consequence of invasion by new mammal species have now been widely documented, especially in isolated ecosystems such as New Zealand (Atkinson 2006) and other oceanic archipelagos. It is clear that invasive mammals are capable of causing radical change to ecosystems that they invade, not only by extinguishing native prey species and altering plant communities, but also by disrupting patterns of nutrient flow. An example of such effects is the trophic cascade generated by the introduction of Arctic foxes to the Aleutian archipelago (Croll et al. 2005). By preying on seabirds and greatly reducing their abundance, the foxes also reduced the input of marine nutrients (imported by seabirds to their breeding colonies) to invaded islands. This subsequently changed the soil nutrient regime and caused vegetation to change from grassland to tundra. Similar indirect effects have been obtained in studies of the impacts of Rattus species on offshore islands of New Zealand (Fukami et al. 2006). Comparison of rat-free and rat-invaded islands revealed that predation of seabirds by rats reduced forest soil fertility by disrupting nutrient transport by the seabirds. This fertility reduction led, in turn, to effects on below-ground organisms and the ecosystem processes driven by them. Carbon sequestration in live plants was also indirectly enhanced on the rat-invaded islands (Wardle et al. 2007). In a similar vein, Wardle (2006) has suggested that introduced browsing mammals not only directly affect vegetation but also indirectly alter the decomposer subsystem.

The ultimate ecological impacts of the many introductions of species that have occurred worldwide in recent centuries and decades have yet to be fully felt or understood (Strayer et al. 


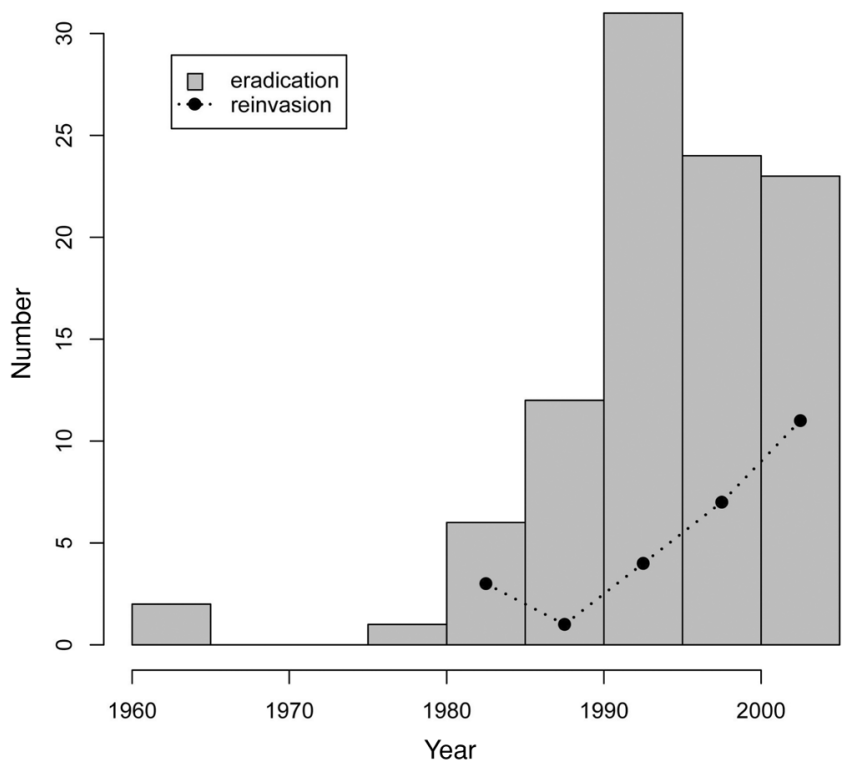

Fig. 2. Eradications and reinvasions of rats on New Zealand islands, 1960-2005. Data extracted from Clout and Russell (2006).

2006). Many introduced mammals are yet to attain the full extent of their distributions, and global climate change may influence the potential range that species could occupy. Local genetic adaptation and even divergent evolution are also possible over long periods (Gleeson et al. 2006). It is nevertheless clear that the risk of new invasions should be minimised and the removal of existing introduced mammals should be seriously considered where possible.

\section{Interactions between invaders}

A topic that merits greater attention when planning eradications is ecosystem responses to species removals. Ecosystems that contain multiple invaders, have lost native species along with their functional roles, or have suffered long-term change to soils, can respond to eradications in unexpected ways (Zavaleta 2002). Interactions between introduced mammals and other invasive species may generate positive feedbacks whereby invasion by different species is enhanced (e.g. Pitman et al. 2005), a process known as 'invasional meltdown' (Simberloff 2006). Interactions between introduced mammals need to be properly understood before eradication or control of one or all of the introduced mammal species at a site is undertaken (Courchamp et al. 2003). For example, 'mesopredator release' (Courchamp et al. 1999) may become evident if a top predator is removed whilst leaving other predators over which this predator may have exerted some previous control. 'Competition release' may similarly occur when an introduced competitor is removed from a system (Caut et al. 2007). More research is needed to understand such potential effects.

\section{Risks of reinvasion}

A final subject that merits more attention in relation to planning the eradication of introduced mammals is the risk of reinvasion. For example, along with recent successes in eradicating rodents from islands there have been several reinvasions. This is illus- trated by data extracted from Clout and Russell (2006), plotting the number of rat eradications from islands in New Zealand alongside the number of rat reinvasions (Fig. 2). Eradications peaked in the early 1990 s, but reinvasions have risen since then, with an apparent lag of $\sim 10$ years. Given the current substantial investment in eradications of introduced mammals from islands around the world, it is vital that we achieve better understanding of how mammals (especially highly dispersive species such as rodents) may be transported or disperse back to sites from which they have been cleared. It is particularly crucial that we research the behaviour and detectability of individual dispersers that are likely to be the founders of new populations. Some experimental work has been undertaken on rats in this context (Russell et al. 2005, 2008) but more is needed.

\section{Conclusion}

Although only a small proportion of the world's land mammals can be classed as 'successful invaders', their ecological impacts are sometimes immense. Many introduced species are yet to attain the full extent of their global and regional distributions. Understanding what determines invasion success, and how introduced mammals interact with each other and with other components of invaded ecosystems, is of fundamental scientific interest (Sax et al. 2005; Cadotte et al. 2006). Such research is also vital in underpinning continued attempts to reverse some of the negative effects of introduced mammals on the world's native biodiversity.

\section{References}

Amori, G., and Clout, M. N. (2003). Rodents on islands: a conservation challenge. In 'Rats, Mice and People: Rodent Biology and Management'. (Eds G. R. Singleton, C. A. Hinds, C. J. Krebs, and D. M. Spratt.) ACIAR Monographs 96, 63-68.

Atkinson, I. A. E. (2006). Introduced mammals in a new environment. In 'Biological Invasions in New Zealand'. (Eds R. B. Allen and W. G. Lee). Ecological Studies 186, 49-66.

Burbidge, A. A., and Manly, B. F. J. (2002). Mammal extinctions on Australian islands: causes and conservation implications. Journal of Biogeography 29, 465-473. doi:10.1046/j.1365-2699.2002.00699.x

Cadotte, M. W., McMahon, S. M., and Fukami, T. (Eds.) (2006). 'Conceptual Ecology and Invasion Biology: Reciprocal Approaches to Nature.' (Springer: Dordrecht.)

Caut, S., Casanovas, J., Virgos, E., Lozano, J., Witmer, G., and Courchamp, F. (2007). Rats dying for mice: modelling the competition release effect. Austral Ecology 32, 858-868.

Ceballos, G., Ehrlich, P. R., Soberon, J., Salazar, I., and Fay, J. P. (2005). Global mammal conservation: what must we manage? Science 309, 603-607. doi:10.1126/science. 1114015

Clout, M. N., and Russell, J. C. (2006). The eradication of mammals from New Zealand islands. In 'Assessment and Control of Biological Invasion Risks'. (Eds F. Koike, M. N. Clout, M. Kawamichi, M. De Poorter and K. Iwatsuki.) pp. 127-141. (IUCN: Gland.)

Colautti, R. I., and MacIsaac, H. J. (2004). A neutral terminology to define ‘invasive species'. Diversity \& Distributions 10, 135-141. doi:10.1111/ j.1366-9516.2004.00061.x

Courchamp, F., Langlais, M., and Sugihara, G. (1999). Cats protecting birds: modelling the mesopredator release effect. Journal of Animal Ecology 68, 282-292. doi:10.1046/j.1365-2656.1999.00285.x

Courchamp, F., Chapuis, J.-L., and Pascal, M. (2003). Mammal invaders on islands: impact, control and control impact. Biological Reviews 78, 347-383. doi:10.1017/S1464793102006061 
Croll, D. A., Maron, J. L., Estes, J. A., Danner, E. M., and Byrd, G. V. (2005). Introduced predators transform subarctic islands from grassland to tundra. Science 307, 1959-1961. doi:10.1126/science.1108485

Duncan, R. P., and Forsyth, D. M. (2006). Modelling population persistence on islands: mammal introductions in the New Zealand archipelago. Proceedings of the Royal Society of London. Series B. Biological Sciences 273, 2969-2975. doi:10.1098/rspb.2006.3662

Duncan, R. P., Bomford, M., Forsyth, D. M., and Conibear, L. (2001). High predictability in introduction outcomes and the geographic range size of introduced Australian birds: a role for climate. Journal of Animal Ecology 70, 621-632.

Forsyth, D. M., and Duncan, R. P. (2001). Propagule size and the relative success of exotic ungulate and bird introductions to New Zealand. American Naturalist 157, 583-595. doi:10.1086/320626

Forsyth, D. M., Duncan, R. P., Bomford, M., and Moore, G. (2004). Climatic suitability, life-history traits, introduction effort, and the establishment and spread of introduced mammals in Australia. Conservation Biology 18, 557-569. doi:10.1111/j.1523-1739.2004.00423.x

Fukami, T., Wardle, D. A., Bellingham, P. J., Mulder, C. P. H., Towns, D. R., Yeates, G. W., Bonner, K. I., Durett, M. S., Grant-Hoffman, M. N., and Williamson, W. M. (2006). Above- and below-ground impacts of introduced predators in seabird-dominated island ecosystems. Ecology Letters 9, 1299-1307. doi:10.1111/j.1461-0248.2006.00983.x

Gleeson, D., Harman, H., and Armstrong, T. (2006). Genetics of invasive species in New Zealand. In 'Biological Invasions in New Zealand'. (Eds R. B. Allen and W. G. Lee.) Ecological Studies 186, 103-118.

Gosling, L. M., and Baker, S. J. (1989). The eradication of muskrats and coypus from Britain. Biological Journal of the Linnean Society 38, $39-51$.

Jeschke, J. M., and Strayer, D. L. (2005). Invasion success of vertebrates in Europe and North America. Proceedings of the National Academy of Sciences of the United States of America 102, 7198-7202. doi:10.1073/ pnas. 0501271102

Kolar, C. S., and Lodge, D. M. (2001). Progress in invasion biology: predicting invaders. Trends in Ecology \& Evolution 16, 199-204. doi:10.1016/S0169-5347(01)02101-2

Lever, C. (1985). 'Naturalized Mammals of the World.' (Longman: London.)

Long, J. L. (2003). 'Introduced Mammals of the World: Their History, Distribution and Influence.' (CSIRO Publishing: Melbourne.)

Mack, R. N., Simberloff, D., Lonsdale, W. M., Evans, H., Clout, M. N., and Bazazz, F. (2000). Biotic invasions: causes, epidemiology, global consequences and control. Ecological Applications 10, 689-710. doi:10.1890/ 1051-0761(2000)010[0689:BICEGC]2.0.CO;2

Myers, K. (1986). Introduced vertebrates in Australia, with emphasis on the mammals. In 'Ecology of Biological Invasions: an Australian
Perspective' (Eds R. Groves and J. Burdon.) pp 120-136. (Australian Academy of Science: Canberra.)

Pitman, R. L., Ballance, L. T., and Bost, C. (2005). Clipperton Island: pig sty, rat hole and booby prize. Marine Ornithology 33, 193-194.

Russell, J. C., Clout, M. N., and McArdle, B. H. (2004). Island biogeography and the species richness of introduced mammals on New Zealand offshore islands. Journal of Biogeography 31, 653-664.

Russell, J. C., Towns, D. R., Anderson, S. H., and Clout, M. N. (2005). Intercepting the first rat ashore. Nature 437, 1107. doi:10.1038/ $4371107 \mathrm{a}$

Russell, J. C., Beaven, B. M., MacKay, J. W. B., Towns, D. R., and Clout, M. N. (2008). Testing island biosecurity systems for invasive rats. Wildlife Research 35, 215-221. doi:10.1071/WR07032

Sax, D. F., Stachowicz, J. J., and Gaines, S. D. (2005). 'Species Invasions: Insights into Ecology, Evolution and Biogeography.' (Sinauer Associates: Sunderland, MA.)

Simberloff, D. (2006). Invasional meltdown 6 years later: important phenomenon, unfortunate metaphor, or both? Ecology Letters 9, 912-919. doi:10.1111/j.1461-0248.2006.00939.x

Strayer, D. L., Eviner, V. T., Jeschke, J. M., and Pace, M. L. (2006). Understanding the long-term effects of species invasions. Trends in Ecology \& Evolution 21, 645-651. doi:10.1016/j.tree.2006.07.007

Thomson, G. M. (1922). 'The Naturalisation of Plants and Animals in New Zealand.' (Cambridge University Press: Cambridge.)

Towns, D. R., and Broome, K. G. (2003). From small Maria to massive Campbell: forty years of rat eradications from New Zealand islands. New Zealand Journal of Zoology 30, 377-398.

Veitch, C. R., and Clout, M. N. (Eds.) (2002). 'Turning the Tide: the Eradication of Invasive Species'. (IUCN: Gland.)

Wardle, D. (2006). Hidden effects: the belowground consequences of introduced browsing mammals in New Zealand forests. In 'Biological Invasions in New Zealand'. (Eds R. B. Allen and W. G. Lee.) Ecological Studies 186, 307-322.

Wardle, D. A., Bellingham, P., Fukami, T., and Mulder, C. P. H. (2007). Promotion of ecosystem carbon sequestration by invasive predators. Biology Letters 3, 479-482. doi:10.1098/rsb1.2007.0163

Williamson, M. (1996). 'Biological Invasions.' (Chapman \& Hall: London.)

Zavaleta, E. (2002). It's often better to eradicate, but can we eradicate better? In 'Turning the Tide: the Eradication of Invasive Species'. (Eds C. R. Veitch and M. N. Clout.) pp 393-403. (IUCN: Gland.)

Manuscript received 12 July 2007, accepted 15 October 2007 